\title{
Internalization of lucifer yellow in Candida albicans by fluid phase endocytosis
}

\author{
Munira A. Basrai, ${ }^{1}$ Fred Naider ${ }^{2}$ and JefFrey M. BeCKer ${ }^{1 *}$ \\ ${ }^{1}$ Department of Microbiology, University of Tennessee, Knoxville, Tennessee 37996, USA \\ ${ }^{2}$ Department of Chemistry, College of Staten Island, Staten Island, New York 10301, USA
}

(Received 12 December 1989; accepted 20 February 1990)

\begin{abstract}
Lucifer yellow (LY), an impermeable fluorescent dye used as a marker for fluid phase endocytosis, was internalized by Candida albicans. As observed by fluorescence microscopy, incubation of $C$. albicans with $L Y$ in potassium phosphate buffer ( $\mathrm{pH} \mathrm{6.0)}$ and glucose $(2 \%, \mathrm{w} / \mathrm{v})$ resulted in localization of the dye inside vacuoles. Sodium azide and carbonyl cyanide $m$-chlorophenylhydrazone, which are inhibitors of energy metabolism, decreased the uptake of the dye. The optimum temperature for uptake was $30^{\circ} \mathrm{C}$; no internalization was observed at $0{ }^{\circ} \mathrm{C}$. Quantification of cell-associated LY by fluorescence spectrometry showed an uptake linear with time and not saturable over a 400 -fold range of concentration. Thus, $C$. albicans internalized $L Y$ into vacuoles by a nonsaturable and time-, temperature- and energy-dependent process consistent with fluid phase endocytosis. Both the yeast and mould phase of this dimorphic fungus endocytosed LY. Growth in complex medium appeared to be required to enable the cells to internalize LY. However, addition of peptone or yeast extract to the phosphate buffer/glucose assay medium interfered with LY uptake by causing an apparent increase of exocytosis. These studies provide the first evidence of fluid phase endocytosis in $C$. albicans and may explain how some large molecules, such as toxins and cationic proteins, enter $C$. albicans.
\end{abstract}

\section{Introduction}

Cells internalize their own plasma membrane and macromolecules from the environment by a mechanism termed endocytosis (reviewed by Silverstein et al., 1977; Steinman et al., 1983). It is now generally accepted that endocytosis brings about the bidirectional flow of plasma membrane into and out of the cell. There are a wide array of substances that can be internalized by this process such as nutrients, toxins and effector molecules (growth factors, hormones, antibodies and enzymes). Two general types of endocytosis are recognized, namely, fluid phase (Silverstein et al., 1977) and receptor mediated endocytosis (Goldstein et al., 1979). Both processes are time-, temperature- and energy-dependent. In fluid phase endocytosis, molecules in the extracellular medium are incorporated by bulk transport into endocytic vesicles and uptake of the ligand is not saturable. However, in receptor mediated endocytosis the ligand to be internalized binds to the cell membrane before it is

Abbreviations: ASM, amino acid synthetic medium; CCCP, carbonyl cyanide $m$-chlorophenylhydrazone; LY, lucifer yellow. incorporated into endocytic vesicles and uptake of the ligand is saturable.

Recent studies show that Saccharomyces cerevisiae can endocytose mating pheromones and lucifer yellow (LY) from the culture medium (Riezman, 1985). These results raised the possibility that other yeasts may also possess this type of uptake mechanism; our interest in peptide uptake and drug design in Candida albicans prompted us to investigate whether a similar process is operative in this dimorphic fungus, an important opportunistic pathogen (reviewed by Odds, 1988).

On the basis of studies determining the porosity of $S$. cerevisiae and $C$. albicans cell walls, endocytosis would not be expected. The porosity of the yeast cell wall has been studied using polyethylene glycols of different molecular sizes (Scherrer et al., 1974; Cope, 1980) and the threshold of permeability was estimated to correspond to an $M_{\mathrm{r}}$ of 620 and an Einstein-Stokes hydrodynamic radius of $0.81 \mathrm{~nm}$. However, the results of cell wall porosity contrast with the killing effects of several proteins much larger than the size limit proposed. The best studied examples are defensins $\left(M_{\mathrm{r}} 3500-4000\right)$, which are variably cationic, cysteine-rich antimicrobial 
peptides (29-34 residues in length) and are major constituents of azurophil granules of polymorphonuclear neutrophils (Lehrer et al., 1985). They are active in vitro against several micro-organisms, including certain fungi (Selsted et al., 1985). The susceptibility of C. albicans to human defensins depends both on the ionic environment and on the metabolic state of the target cell (Lehrer et al., 1988). The mechanism of action of defensins is not clear, although it has been proposed that they act through membrane perturbation (Selsted et al., 1985). Killer toxins $\left(M_{\mathrm{r}} 15000-25000\right)$, secreted into the culture medium from selected killer yeasts, cause lysis of $C$. albicans (Polonelli et al., 1985). Yphanitis et al. (1967) also reported that certain cationic proteins such as ribonuclease, protamine, bovine serum albumin, cytochrome $c$ and myoglobin cause lysis of $S$. cerevisiae and C. utilis. All these studies point to the fact that these proteins may penetrate the cell wall to act directly on the cell by an undescribed mechanism.

In this paper we report on the characteristics of uptake of LY by the yeast and mould phases of $C$. albicans using fluorescence microscopy and fluorescence spectroscopy. $\mathrm{LY}$, an impermeable fluorescent dye, has been used as a marker for fluid phase endocytosis in mammalian cells and S. cerevisiae (Swanson et al., 1985; Reizman, 1985). This dye offers several advantages for use as a marker for fluid phase endocytosis (Miller et al., 1983; Stewart, 1978,1981 ): a very high quantum yield resulting in easily visualized fluorescence after uptake by cells; small size, allowing passage through the yeast cell wall; stability over a wide range of $\mathrm{pH}$, from $2 \cdot 0-10 \cdot 0$; negative charge at all $\mathrm{pH}$ values above 2.0 and, hence, not diffusable across the cell membrane; not toxic to cells; and fluorescence not quenchable by yeast cell extracts (Riezman, 1985).

\section{Methods}

Organism and growth conditions. Candida albicans $\mathrm{H} 317$, a wellcharacterized (Riggsby et al., 1982) clinical isolate obtained from the Centers for Disease Control, Atlanta, Georgia, USA, was used in all experiments. The strain was maintained on YEPD agar [ $1 \%$, w/v, yeast extract, $2 \%$, w/v, bactopeptone (Difco), $2 \%, w / v$, glucose and $2 \%$, w/v, agar] at $4{ }^{\circ} \mathrm{C}$ and transferred monthly.

For all experiments, unless mentioned otherwise, the yeast phase of growth was obtained in YEPD medium. Cells were inoculated at an initial cell density of $10^{4}$ cells ml-1 in $200 \mathrm{ml}$ YEPD broth and incubated at $37^{\circ} \mathrm{C}$ on a rotary shaker at 200 r.p.m. An exponentially growing culture at a cell density of $1-2 \times 10^{7}$ cells ml$^{-1}$, was used for all experiments. Cells were harvested by centrifugation at $1500 \mathrm{~g}$ for $5 \mathrm{~min}$, washed once with distilled water and twice with $50 \mathrm{~mm}$ potassium phosphate buffer, $\mathrm{pH} 6.0$, and resuspended in phosphate buffer.

The mould phase of growth was obtained using two procedures, one a temperature shift and the other a nutritional shift. For the temperature shift procedure we used the amino acid synthetic medium (ASM) described by Lee et al. (1975) and the procedure of Logan et al. (1983).
Briefly, yeast phase cells were first grown to stationary phase in ASM, $\mathrm{pH} 6.8$, at $25^{\circ} \mathrm{C}$. Cultures were stored at $4^{\circ} \mathrm{C}$ for $12 \mathrm{~h}$. Yeast phase cultures were obtained by diluting stationary phase cultures into fresh medium at $25^{\circ} \mathrm{C}$. Conversion to the mould phase was initiated by diluting $(1: 20)$ the stationary phase culture into fresh medium at $37^{\circ} \mathrm{C}$. The mould phase cultures ( $>90 \%$ conversion) were harvested $12 \mathrm{~h}$ after the initiation of conversion. For nutritional shift conversion (Joshi et al., 1973), yeast cells were grown on Sabouraud dextrose agar for $48 \mathrm{~h}$ at $37^{\circ} \mathrm{C}$. Cells were scraped from the agar and resuspended in water at $1 \times 10^{6}$ cells $\mathrm{ml}^{-1}$, then inoculated into prewarmed $\left(37^{\circ} \mathrm{C}\right) 1 \%$ (w/v) bactopeptone. The mould phase was obtained after $4-5 \mathrm{~h}$ at a frequency of $50-60 \%$.

Visualization of cell-associated lucifer yellow. The procedure for the assay was similar to that described previously for $S$. cerevisiae (Riezman, 1985) with a few variations. C. albicans was grown overnight as described above. The assay was done with $2 \times 10^{7}$ cells in $50 \mathrm{~mm}$ potassium phosphate buffer, $\mathrm{pH} 6 \cdot 0$. Glucose or other additions were made to the cell suspension and, after $15 \mathrm{~min}$ at $30^{\circ} \mathrm{C}$, lucifer yellow $\mathrm{CH}$ (Molecular Probes, Eugene, Oregon, USA) was added to a final concentration of $4 \mathrm{mg} \mathrm{ml}^{-1}$. After the indicated time of incubation cells were diluted with $5 \mathrm{ml}$ of ice-cold buffer A ( $50 \mathrm{mM}$-succinic acid/ $\mathrm{NaOH}$, pH 5.0, containing $100 \mathrm{mM}-\mathrm{NaCl}, 10 \mathrm{mM}-\mathrm{MgCl}_{2}, 20 \mathrm{mM}-$ $\mathrm{NaN}_{3}$ ), collected by vacuum filtration on nitrocellulose filters ( $\mathrm{GN}-6$, $0.46 \mu \mathrm{m}$ ) washed four times with $2 \mathrm{ml}$ buffer $A$ and once with $2 \mathrm{ml}$ $50 \mathrm{mM}$-Tris/HCl, pH 7.25. The cells were eluted off the filter with the Tris/ $/ \mathrm{HCl}$ buffer and the suspension was kept on ice. For visualization of cell-associated LY, the cells were mounted on a slide precoated with $20 \mu 11 \mathrm{mg}$ concanavalin $\mathrm{A} \mathrm{ml}^{-1}$, which immobilized the yeast cells. Fluorescence was observed with a Leitz Orthoplan microscope with a xenon mercury lamp equipped with epifluorescence using an excitation filter BP $450-490$, a beam splitting mirror TK 495 and a suppression filter K530. Photographs were taken using Ektachrome 200 ASA with exposure of $50-60 \mathrm{~s}$.

Quantification of cell-associated lucifer yellow. For quantification of cell-associated LY, cells were incubated in assay medium containing $2 \%(\mathrm{w} / \mathrm{v})$ glucose and various concentrations of LY in $50 \mathrm{~mm}-$ potassium phosphate buffer, $\mathrm{pH} 6 \cdot 0$. A portion of the cell suspension was removed at various time points and the cells were washed as described above. Appropriate dilutions of the cells were used to quantify cell-associated LY using a luminescence spectrometer model LS-5B (Perkin Elmer), with excitation at $426 \mathrm{~nm}$ and emission at $535 \mathrm{~nm}$ (slit widths 10 and $20 \mathrm{~nm}$, respectively); a standard curve was produced using known amounts of LY. Haemocytometer counts of each sample were determined to account for non-uniform elution of cells from the nitrocellulose filters. Each experiment was repeated at least three times with values not differing by more than $10 \%$ of each other.

Exocytosis of lucifer yellow. C. albicans cells grown in YEPD medium were harvested in the exponential phase, washed, incubated in assay medium containing $2 \%(\mathrm{w} / \mathrm{v})$ glucose and LY $\left(1 \mathrm{mg} \mathrm{ml}^{-1}\right)$ in $50 \mathrm{~mm}$ potassium phosphate buffer, $\mathrm{pH} 6 \cdot 0$, at $30^{\circ} \mathrm{C}$ for $90 \mathrm{~min}$, collected and washed on filters as described above, and eluted from filters into phosphate buffer. Cells were then re-incubated either in phosphate buffer or in $2 \%(\mathrm{w} / \mathrm{v})$ peptone at $30^{\circ} \mathrm{C}$. A portion of the cell suspension was removed at various time points and centrifuged. Fluorescence associated with the cells and in the supernatant was quantified as described above.

Column chromatography. Column chromatography of LY and a mixture of LY and peptone was done using Sephadex G-25, dry bead diameter $50-150 \mu \mathrm{m}$. The column $(1.5 \times 8 \mathrm{~cm})$ was equilibrated with $50 \mathrm{~mm}$-potassium phosphate buffer, pH 6.0. The downward flow elution rate during the packing was controlled by a peristaltic pump to give a flow rate of $1 \mathrm{ml} \mathrm{min}^{-1}$. A sample $(200 \mu \mathrm{l})$ containing LY $(37.5 \mu \mathrm{g}$ 
$\mathrm{ml}^{-1}$ ) was applied to the column, $1 \mathrm{ml}$ fractions were collected and fluorescence was determined using the fluorescence spectrometer. A second sample $(200 \mu \mathrm{l})$ containing LY $\left(37.5 \mu \mathrm{g} \mathrm{ml}^{-1}\right)$ plus peptone $\left(500 \mu \mathrm{g} \mathrm{ml}^{-1}\right.$ ) was incubated at $30^{\circ} \mathrm{C}$ for $90 \mathrm{~min}$ and then applied to the column. Fractions were collected and fluorescence and protein of each fraction was determined. The protein in each fraction was measured using a dye binding protein assay (Bio-Rad) with bovine serum albumin as standard.

\section{Results}

Effect of temperature and energy inhibition on uptake of lucifer yellow by the yeast phase of $C$. albicans

An optimum temperature of $30^{\circ} \mathrm{C}$ for the uptake of LY by $C$. albicans was determined in buffered glucose medium during a $90 \mathrm{~min}$ incubation; $80-90 \%$ of the cells internalized $\mathrm{LY}$ at $30^{\circ} \mathrm{C}$. Cells incubated at 22,37 and $42{ }^{\circ} \mathrm{C}$ internalized $\mathrm{LY}$ at levels 50,22 and $75 \%$ less, respectively, than the levels internalized at $30^{\circ} \mathrm{C}$. Intracellular fluorescence appeared in vacuoles; some cells showed many small vacuoles, while others had two or three large vacuoles (Fig. 1 $a, b$ ). There was no internalization at $0{ }^{\circ} \mathrm{C}$. A few cells showed entrapment of the dye between the cell wall and cell membrane at all the temperatures studied (Fig. 1c).

The energy-dependence of uptake of LY by $C$. albicans was studied during a $90 \mathrm{~min}$ incubation at $30^{\circ} \mathrm{C}$. Cells incubated in $2 \%(\mathrm{w} / \mathrm{v})$ glucose internalized $\mathrm{LY}$ into vacuoles as described above. Cells incubated with $2 \%$ $(\mathrm{w} / \mathrm{v})$ glucose in the presence of $20 \mathrm{~mm}-\mathrm{NaN}_{3}$, an energy inhibitor, did not internalize the dye into vacuoles. However, $1-2 \%$ of cells appeared to have the dye diffuse throughout the cytoplasm and not localized in discrete vacuoles. Cells incubated with $20 \mathrm{~mm}-\mathrm{NaN}_{3}$ in the absence of glucose did not internalize the dye. Only 10 $20 \%$ of the cells incubated with $2 \%$ glucose and $25 \mu \mathrm{M}-$ CCCP, an uncoupler of $\mathrm{H}^{+}$gradients (Harold, 1986), accumulated LY into apparently discrete vacuoles. Cellular fluorescence was not reduced when cells were incubated with $2 \%$ glucose and $8 \mathrm{~mm}$-sodium orthovanadate, which acts on membrane-associated ATPases (Hubbard et al., 1985, 1986).

\section{Quantitative assays for lucifer yellow uptake}

We quantified cell-associated LY to determine if the uptake of the dye by the yeast phase of $C$. albicans was time-dependent and saturable. Cells were incubated for various periods of time in assay medium containing LY $\left(0 \cdot 1,1,2\right.$ and $\left.4 \mathrm{mg} \mathrm{ml}^{-1}\right)$. Quantification of cellassociated LY for each concentration of LY at different time points suggested that the uptake of the dye by $C$. albicans increased over a $2 \mathrm{~h}$ incubation period (Fig. 2). The uptake of LY was not saturable over a 400 -fold range of concentration tested (inset Fig. 2).

\section{Internalization of lucifer yellow by the mould phase of C. albicans}

Studies with the yeast phase of $C$. albicans prompted us to investigate if the mould phase of this dimorphic fungus internalized LY. The mould phase was obtained by a nutritional shift and assays were done for $90 \mathrm{~min}$ at both $30{ }^{\circ} \mathrm{C}$, the optimum temperature for internalization of $\mathrm{LY}$ by the yeast phase, and also $37^{\circ} \mathrm{C}$, the temperature at which the mould phase was obtained. The mould phase internalized LY at both 30 and $37^{\circ} \mathrm{C}$ and the dye was localized either in several small vacuoles or in large vacuoles distributed all along the length of the mycelium (Fig. $1 d, e$ ).

Effect of growth medium on the uptake of lucifer yellow by the yeast and mould phases of C. albicans

Yeast and mould phases obtained by growth in ASM were assayed for LY uptake during a $90 \mathrm{~min}$ incubation in medium containing $4 \mathrm{mg} \mathrm{LY} \mathrm{ml} \mathrm{mb}^{-1}$. Yeast cells obtained by growth at $25^{\circ} \mathrm{C}$ did not internalize LY at either 25 or $30^{\circ} \mathrm{C}$, the optimum temperature for $\mathrm{LY}$ internalization by the yeast phase grown in YEPD. Also, the mould phase generated by a temperature shift procedure in ASM did not internalize LY when assays were done at 30 or $37^{\circ} \mathrm{C}$.

\section{Effect of peptone and yeast extract on the uptake of lucifer yellow by C. albicans}

The observation that the yeast phase or mould phase grown in complex medium internalized LY, whereas both phases grown in ASM did not, led us to determine if peptone or yeast extract affected LY internalization. Cells were grown in complex medium and assays were done at $30^{\circ} \mathrm{C}$ for $90 \mathrm{~min}$. Only $10-20 \%$ of the cells internalized LY in the presence of $0.5-2 \%$ peptone or yeast extract, whereas $80-90 \%$ of the cells internalized LY without peptone or yeast extract addition. In order to investigate if peptone complexed with LY and thus made it unavailable for endocytosis, we performed column chromatography of LY and an LY-peptone mixture using Sephadex G-25. The elution profile of LY was not affected by co-chromatography with peptone when applied as a mixture of peptone and LY. The peptone components were distributed over all the fractions collected.

\section{Exocytosis of lucifer yellow}

Since peptone in the assay medium reduced LY internalization, we determined if peptone affected exocytosis of internalized LY from the yeast phase of $C$. albicans. Cells were incubated in assay medium contain- 

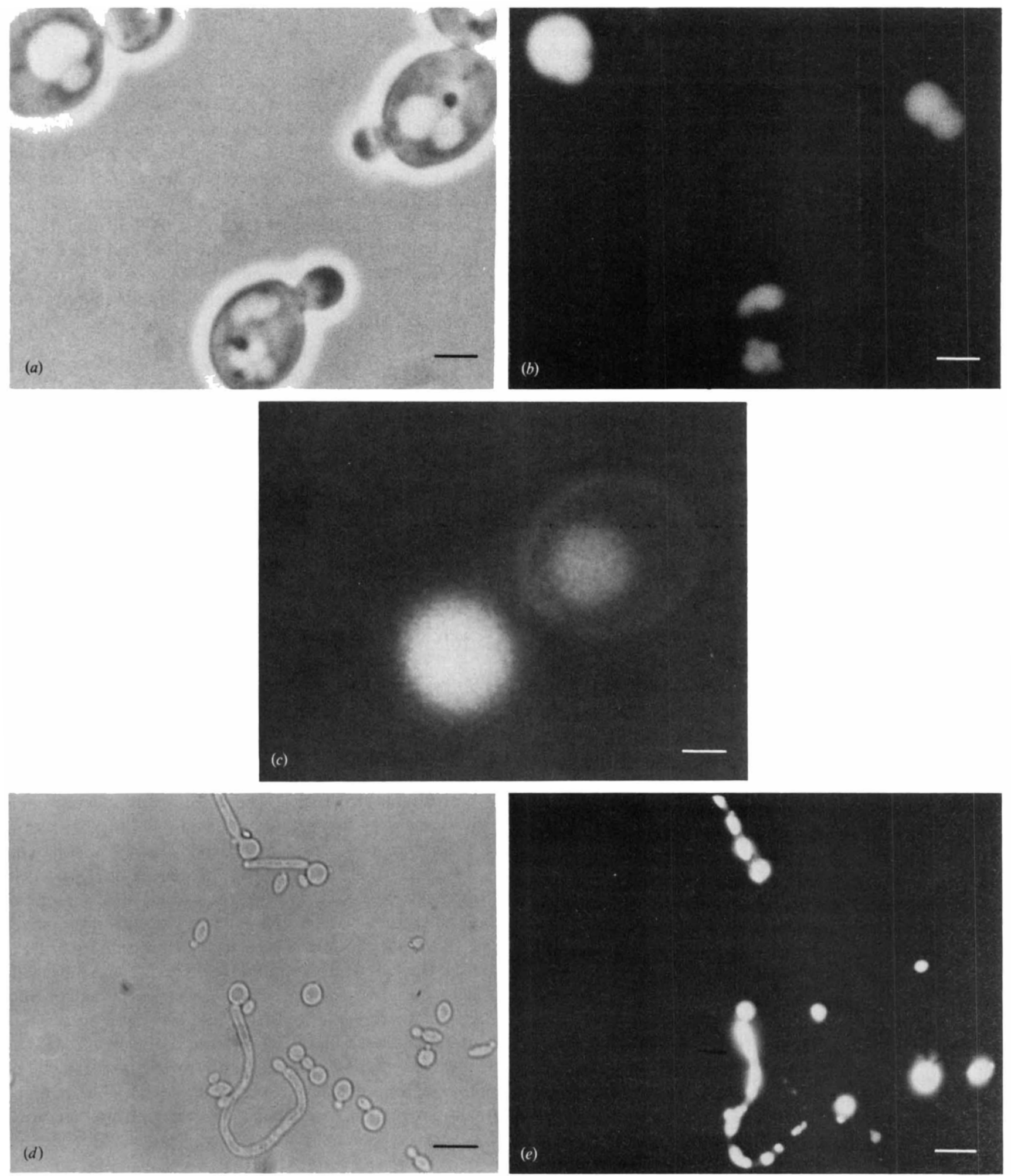

Fig. 1. Internalization of LY by C. albicans. Cells were incubated in assay medium containing $2 \%(w / v)$ glucose and $4 \mathrm{mg} \mathrm{LY} \mathrm{ml}^{-1}$ in $50 \mathrm{~mm}$-potassium phosphate buffer, $\mathrm{pH} 6.0$, at $30^{\circ} \mathrm{C}$ for $90 \mathrm{~min}$. Cells were washed and visualized by phase contrast and fluorescence microscopy. (a) Phase contrast micrograph. (b) Fluorescence micrograph of the same field as in (a) showing uptake of the dye inside vacuoles. (c) Fluorescence micrograph showing entrapment of the dye as indicated by fluorescence around the cellular periphery. (d) Phase contrast micrograph of the mould phase. (e) Fluorescence micrograph of the same field as in $(d)$ showing intracellular accumulation of the dye inside vacuoles. Bars: $(a),(b),(c), 1 \mu \mathrm{m} ;(d),(e), 5 \mu \mathrm{m}$. 


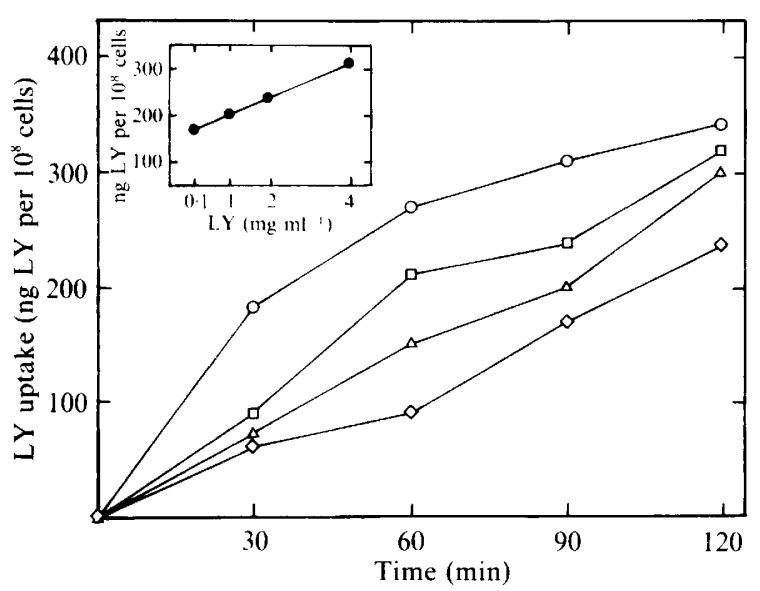

Fig. 2. Time course of uptake of LY by $C$. albicans. Cells were incubated with various concentrations of LY $\left(\diamond, 0.1 \mathrm{mg} \mathrm{ml}^{-1} ; \triangle\right.$, $1 \mathrm{mg} \mathrm{ml}^{-1} ; \square, 2 \mathrm{mg} \mathrm{ml}^{-1} ; 0,4 \mathrm{mg} \mathrm{ml}^{-1}$ ) in assay medium containing $2 \%(\mathrm{w} / \mathrm{v})$ glucose in $50 \mathrm{~mm}$-potassium phosphate buffer, $\mathrm{pH} 6.0$, at $30^{\circ} \mathrm{C}$. Cell-associated LY was quantified using a fluorescence spectrometer. Inset, nonsaturable uptake of LY. Cell-associated LY values for the $90 \mathrm{~min}$ time point (O) were replotted for each concentration of $\mathrm{LY}$.

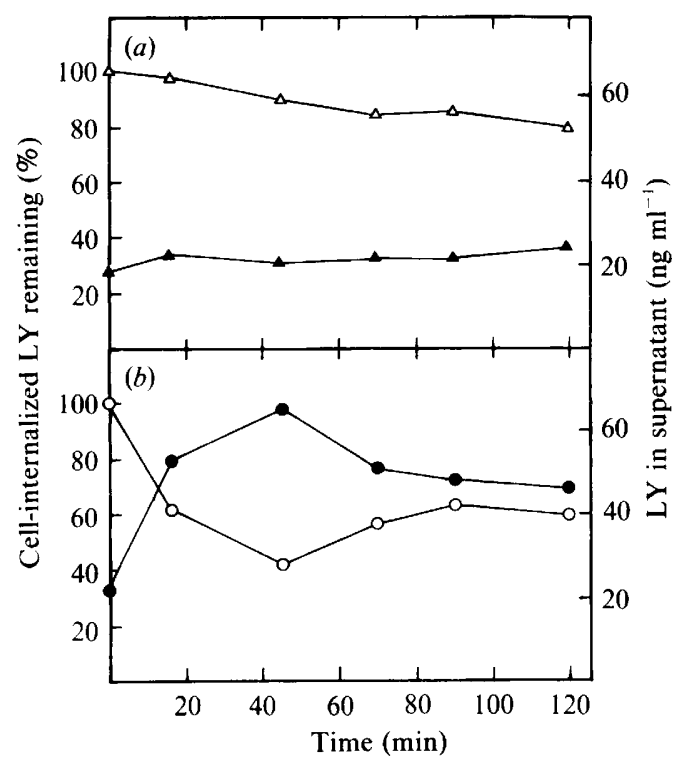

Fig. 3. Exocytosis of LY. C. albicans cells incubated with $2 \%$ glucose and $1 \mathrm{mg} \mathrm{LY} \mathrm{ml}^{-1}$ in $50 \mathrm{~mm}$-potassium phosphate buffer, $\mathrm{pH} \mathrm{6.0,} \mathrm{at}$ $30^{\circ} \mathrm{C}$ for $90 \mathrm{~min}$, were washed and re-incubated in phosphate buffer $(a)$, or $2 \%(w / v)$ peptone $(b)$, for various time periods at $30^{\circ} \mathrm{C}$. Fluorescence associated with the cells $(\triangle, O)$ and supernatant $(\boldsymbol{\Lambda}, \boldsymbol{O})$, was measured.

ing $1 \mathrm{mg} \mathrm{LY} \mathrm{ml}{ }^{-1}$ at $30^{\circ} \mathrm{C}$ for $90 \mathrm{~min}$, washed, then reincubated in the presence or absence of $2 \%(\mathrm{w} / \mathrm{v})$ peptone. Results of this experiment (Fig. 3) show that yeast cells re-incubated with peptone lost nearly $60 \%$ of cell-associated LY within $50 \mathrm{~min}$ with a concomitant increase in the fluorescence of the supernatant. Cells reincubated in phosphate buffer retained about $80 \%$ of the cell-associated LY even after re-incubation for $2 \mathrm{~h}$.

\section{Viability of lucifer yellow treated cells}

C. albicans cells were incubated in a medium containing $4 \mathrm{mg} \mathrm{LY} \mathrm{ml} \mathrm{m}^{-1}$ at $30^{\circ} \mathrm{C}$ for $90 \mathrm{~min}$. After examining cells under the fluorescence microscope appropriate dilutions of cells were plated on YEPD agar plates. Control cells incubated without LY were also plated and the counts were compared. After incubation at $37^{\circ} \mathrm{C}$ for $48 \mathrm{~h}, 98 \%$ of the control cells were viable as compared to $88 \%$ of the LY treated cells (values are means of three experiments). Thus, uptake of LY did not greatly affect cell viability.

\section{Discussion}

In this report, we have shown that LY is internalized by C. albicans in a non-saturable and time-, temperatureand energy-dependent, process consistent with the characteristics of fluid phase endocytosis. The dye appeared to be concentrated inside vacuoles similar to those observed in $S$. cerevisiae (Riezman, 1985). A genetic basis for the involvement of vacuoles in endocytosis has been shown in $S$. cerevisiae. A temperature sensitive mutant, which lacked a morphologically recognizable vacuole, was defective for vacuolar enzyme biogenesis and was unable to internalize lucifer yellow (Chvatchko et al., 1986; Reizman et al., 1986; Dulic \& Riezman, 1989).

Energy-dependence of uptake of the dye is reflected by the finding that glucose in the assay medium allowed the internalization of LY, while inhibitors of energy metabolism decreased the internalization of the dye. $\mathrm{NaN}_{3}$, in the absence of glucose, probably blocks even the basal level of metabolism and, hence, no internalization was observed. The diffuse fluorescence in the presence of glucose and $\mathrm{NaN}_{3}$ might indicate a non-endocytic uptake into poisoned cells, as $\mathrm{NaN}_{3}$ has been reported to interact with the yeast cell membrane causing an increase in membrane permeability (Riemersma, 1968). Sodium orthovanadate, which inhibits fungal plasma membrane ATPases (Hubbard et al., 1985, 1986; Goffeau \& Slayman, 1981; Willsky, 1979), might be expected to reduce cellular fluorescence of LY due to the central role of ATPases in energy metabolism. However, in both S. cerevisiae (Riezman, 1985) and C. albicans, intracellular fluorescence does not seem to be reduced in the presence of sodium orthovanadate. It is possible that the membrane-associated ATPases are dispensable for endocytosis in $C$. albicans and $S$. cerevisiae, or that 
vanadate is metabolized to vanadyl ions leading to stimulatory effects on yeast cells (Dubyak \& Kleinzeller, 1980; Willsky et al., 1984).

C. albicans is a dimorphic fungus which undergoes yeast to mould phase conversion when provided with appropriate environmental conditions. Lee et al. (1975) developed a synthetic medium composed of amino acids, salts, glucose and biotin which maintained this fungus in the yeast form at $25^{\circ} \mathrm{C}$ and in the mould form at $37^{\circ} \mathrm{C}$. Surprisingly, we found that neither the mould phase nor the yeast phase grown in synthetic medium internalized LY even though distinct vacuoles could be seen in the cells by phase contrast microscopy. However, both phases grown in complex medium and assayed for LY uptake in buffered glucose medium internalized LY into vacuoles. These results suggest that growth in a complex medium triggers the process of fluid phase endocytosis.

The influence of growth conditions on uptake processes in $C$. albicans has been investigated by several workers. Recently, Skowronski \& Feldman (1989) reported that significant binding of oestrogen to oestrogen-binding protein in C. albicans could only be found if yeast cells were grown in complex medium whereas negligible binding was seen when cells were grown in some synthetic media. Page \& Odds (1988) reported that the growth medium affects binding of human albumin, fibrinogen and transferrin to C. albicans and found that the mould phase obtained by growth in a synthetic medium bound less protein. Logan et al. (1979) have shown that the nitrogen source for growth affected peptide transport in C. albicans.

Since growth in complex media appeared to be required to enable cells to internalize $L Y$, we investigated the effect of addition of peptone and yeast extract to the assay medium. Our results showed that peptone and yeast extract in the assay medium reduced the number of fluorescent cells, and that this was not due to complex formation between peptone and LY. Rather, peptone caused a rapid increase in efflux of internalized LY. Exocytosis of endocytosed material has been shown to be stimulated by extracellular calcium (Besterman et al., 1981) and chloroquine (Kotal \& Kotyk, 1988). Further experiments are required to elucidate the mechanisms operating in these processes.

Studies on fluid phase endocytosis in C. albicans may explain how some large molecules such as defensins (Lehrer et al., 1985), toxins (Polonelli et al., 1985) and cationic proteins (Yphanitis et al., 1967; Olson et al., 1977) cause cell damage. Since the characterized oligopeptide permeases are not known to transport such large proteins (Becker \& Naider, 1980), and since no receptors have been reported for these large molecules, it is possible that they enter cells by fluid phase endocytosis.
A relationship between endocytosis and secretion has been reported for $S$. cerevisiae (Riezman, 1985; Dulic \& Riezman, 1989), as several yeast secretory mutants were defective in internalization of LY. It is possible, therefore, that studies on endocytosis may increase our understanding on how proteinases are secreted from $C$. albicans. Secretion of proteinase $\left(M_{\mathrm{r}} 40000-50000\right)$ is an example of a protein crossing the cell wall barrier despite the apparent $M_{\mathrm{r}}$ limit of 600 proposed for cell wall porosity (Scherrer et al., 1974; Cope, 1980). The secreted proteinase of $C$. albicans has been implicated as a virulence factor by several workers (reviewed in Douglas, 1988), although reports to the contrary also exist (Burnie et al., 1985). It will be interesting to investigate if the endocytic and secretory pathways of $C$. albicans are coupled by studying LY endocytosis in C. albicans proteinase deficient mutants (Kwon-Chung et al., 1985).

This work was supported by American Cancer Society grant BC-626. We thank Stevan Marcus for helpful discussions and comments on the manuscript.

\section{References}

BECKER, J. M. \& NAIDER, F. (1980). Transport and utilization of peptides by yeast. In Transport and Utilization of Amino Acids, Peptides and Proteins by Microorganisms. Edited by J. W. Payne. London: John Wiley.

Besterman, J. M., Airhart, J. A., Woodworth, R. C. \& Low, R. B. (1981). Exocytosis of pinocytosed fluid in cultured cells: kinetic evidence for rapid turnover and compartmentation. Journal of Cell Biology 91, 716-727.

Burnie, J. P., Odds, F. C., Lee, W., Webster, C. \& Williams, J. D. (1985). Outbreak of systematic Candida albicans in intensive care unit caused by cross infection. British Medical Journal 290, 746-748.

ChyatchKo, Y., Howald, I. \& Riezman, H. (1986). Two yeast mutants defective in endocytosis are defective in pheromone response. Cell 46, 355-364.

COPE, J. E. (1980). The porosity of the cell wall of Candida albicans. Journal of General Microbiology 119, 253-255.

Douglas, L. J. (1988). Candida proteinases and candidosis. CRC Critical Reviews in Biotechnology 8, 121-129.

DubYAK, G. \& KLeINZELler, A. (1980). The insulin mimetic effects of vanadate in isolated rat adipocytes. Journal of Biological Chemistry 255, 5306-5312.

DulIC, V. \& RIEZMAN, H. (1989). Characterization of the END1 gene required for vacuole biogenesis and gluconeogenic growth of budding yeast. EMBO Journal 8, 1349-1359.

Goldstein, J. L., ANDerson, R. W. \& Brown, M. S. (1979). Coated pits, coated vesicles, and receptor-mediated endocytosis. Nature, London 279, 679-685.

Goffeau, A. \& Slayman, C. W. (1981). The proton-translocating ATPases of the fungal plasma membrane. Biochimica et Biophysica Acta 639, 197-223.

HaROLD, F. M. (1986). The Vital Force: A Study of Bioenergetics. New York: W. H. Freeman.

Hubbard, M. J., Sullivan, P. A. \& Shepherd, M. G. (1985). The kinetics and divalent cation inhibition of plasma membrane ATPases in the yeast Candida albicans. Journal of Biological Chemistry 260, 6782-6787.

Hubbard, M., Surarit, R., Sullivan, P. \& Shepherd, M. (1986). The isolation of plasma membrane and characterisation of the plasma membrane ATPases from the yeast Candida albicans. European Journal of Biochemistry 154, 375-381. 
Joshi, K. R., Gavin, J. B. \& Bremer, D. A. (1973). The formation of germ tubes by Candida albicans in various peptone media. Sabouraudia 11, 259-262.

KoTAL, P. \& KoTYK, A. (1988). Exocytosis as a possible mechanism for the secretion of coproporphyrin from chloroquine-treated yeast. European Journal of Pharmacology 155, 301-303.

Kwon-Chung, K., Lehman, D., Good, C. \& Magee, P. (1985). Genetic evidence for role of extracellular proteinase in virulence of Candida albicans. Infection and Immunity 49, 571-575.

Lee, K. L., Buckley, R. H. \& Campbell, C. C. (1975). An amino acid liquid synthetic medium for the development of mycelial and yeast forms of Candida albicans. Sabouraudia 13, 148-153.

LeHRER, R., SZKLAREK, D., GANZ, T. \& SelSTED, M. (1985). Correlation of binding of rabbit granulocyte peptides to Candida albicans with candidacidal activity. Infection and Immunity 49, 207-211.

Lehrer, R., Ganz, T., Szklarex, D. \& Selsted, M. (1988). Modulation of the in vitro candidacidal activity of human neutrophil defensins by target cell metabolism and divalent cations. Journal of Clinical Investigation 81, 1829-1835.

Logan, D. A., NaIDER, F. \& BeCKer, J. M. (1979). Peptide transport in Candida albicans. Journal of General Microbiology 114, 179-186.

Logan, D. A., NAIDER, F. \& BeCKer, J. M. (1983). Peptidases of yeast and filamentous forms of Candida albicans. Experimental Mycology 7 , 116-126.

Miller, D. K., Griffiths, E., Lenard, J. \& Firestone, R. A. (1983). Cell killing by lysomotropic detergents. Journal of Cell Biology 97, 1841-1851.

ODDs, F. C. (1988). Candida and Candidosis, 2nd edn. London: Balliere Tindall.

Olson, V. L., Hansing, R. L. \& McClaRY, D. O. (1977). The role of metabolic energy in the lethal action of basic proteins on Candida albicans. Canadian Journal of Microbiology 23, 166-174.

PAGE, S. \& ODDS, F. C. (1988). Binding of plasma proteins to Candida species in vitro. Journal of General Microbiology 134, 2693-2702.

Polonelli, L., Castagnola, M., Rossetti, D. \& Morace, G. (1985). Use of killer toxins for computer-aided differentiation of Candida albicans strains. Mycopathologia 91, 175-179.

RIEMERSMA, J. C. (1968). Effects of sodium azide and 2,4-dinitrophenol on phosphorylation reactions and ion fluxes in Saccharomyces cerevisiae. Biochimica et Biophysica Acta 153, 80-87.
RIEZMAN, H. (1985). Endocytosis in yeast : several of the yeast secretory mutants are defective in endocytosis. Cell 40, 1001-1009.

Riezman, H., ChvatchKo, Y. \& Dulic, V. (1986). Endocytosis in yeast. Trends in Biochemical Sciences 11, 325-328.

Riggsby, W. S., Torres-BauZa, L. J., Wills, J. W. \& Townes, T. M. (1982). DNA content, kinetic complexity, and the ploidy question in Candida albicans. Molecular and Cellular Biology 2, 853-862.

SCherrer, R., Louden, L. \& GerhardT, P. (1974). Porosity of the yeast cell wall and membrane. Journal of Bacteriology 118, 534-540.

Selsted, M. E., Szlarek, D., Ganz, T. \& Lehrer, R. I. (1985). Activity of rabbit leukocyte peptides against Candida albicans. Infection and Immunity 49, 202-206.

Silverstein, S. C., Steinman, R. M. \& Cohn, Z. A. (1977). Endocytosis. Annual Review of Biochemistry 46, 669-722.

SkowronsKi, R. \& FeldmaN, D. (1989). Characterization of an estrogen-binding protein in the yeast Candida albicans. Endocrinology 124, 1965-1972.

Steinman, R. M., Mellman, I. S., Muller, W. A. \& Cohn, Z. A. (1983). Endocytosis and the recycling of plasma membrane. Journal of Cell Biology 96, 1-27.

STEWART, W. W. (1978). Functional connections between cells as revealed by dye-coupling with a highly fluorescent naphthalimide tracer. Cell 14, 741-759.

StEWART, W. W. (1981). Lucifer dyes - highly fluorescent dyes for biological tracing. Nature, London 292, 17-21.

Swanson, J. A., YiRINec, B. D. \& Silverstein, S. C. (1985). Phorbol esters and horseradish peroxidase stimulate pinocytosis and redirect the flow of pinocytosed fluid in macrophages. Journal of Cell Biology 100, 851-859.

WILLSKY, G. R. (1979). Characterization of the plasma membrane $\mathrm{Mg}^{2+}$-ATPases from the yeast Saccharomyces cerevisiae. Journal of Biological Chemistry 254, 3326-3332.

WILLSKY, G. R., WHITE, D. A. \& MCCABE, B. C. (1984). Metabolism of added orthovanadate to vanadyl and high-molecular weight vanadates by Saccharomyces cerevisiae. Journal of Biological Chemistry 259, 13273-13281.

YPHANITIS, D. A., DaINKo, J. L. \& SCHLENK, F. (1967). Effect of some proteins on the yeast cell membrane. Journal of Bacteriology 94, 1509-1515. 